\title{
Regional Development Policies Practiced in the Rural Development Approach in Malaysia: A Case Study in Seberang Perai
}

\author{
Kamarudin $\operatorname{Ngah}^{1}$, Zaherawati Zakaria ${ }^{2}$, Jamaludin Mustaffa ${ }^{3} \&$ Nazni Noordin $^{2}$ \\ ${ }^{1}$ Pusat Penyelidikan Dasar dan Kajian Antarabangsa (CenPRIS), Universiti Sains Malaysia (USM), Pulau \\ Pinang, Malaysia \\ ${ }^{2}$ Faculty of Administrative Science \& Policy Studies, Universiti Teknologi MARA, Merbok, Malaysia \\ ${ }^{3}$ College of Arts and Science, Universiti Utara Malaysia, Sintok, Malaysia \\ Correspondence: Zaherawati Zakaria, Faculty of Administrative Science \& Policy Studies, Universiti Teknologi \\ MARA, P. O Box 187, 08400 Merbok, Kedah, Malaysia. Tel: 60-4-456-2565 E-mail: \\ zaherawati@kedah.uitm.edu.my
}

Received: April 1, 2012 Accepted: May 7, 2012 Online Published: August 30, 2012

doi:10.5539/ass.v8n11p186

URL: http://dx.doi.org/10.5539/ass.v8n11p186

\begin{abstract}
The characteristics and the needs of the developing countries based on agriculture is rely on one of the integrated approaches known as the Traditional Village Development Approach is stressed for the regional development in Malaysia. This scenario occurs due to the failure of the previous regional development policies, particularly the limited spillover effects, has encouraged a more integrated approach. The objective of this approach is to lessen the disproportionate gap between the urban and rural areas, and at the same time upgrade the villagers' standard of living. This strategy includes agricultural improvement through ownership changes and small farm consolidation into plantations, the development of non-economic activities and the changes in settlement structure and the establishment of the growth centers. The findings of the study showed that there is still some space for action that needs to be taken in order to develop the standard of living of the rural population, particularly in identifying the priorities for the development and the overall development strategy. The most important thing is to ensure that the returns and a more optimum benefit are given to the population through a more comprehensive and collective participation.
\end{abstract}

Keywords: regional, development, policies, rural, local, government

\section{Introduction}

The period of the mid-seventies saw a new development reorientation with a vital policy transformation in regional development planning. The focus switched from the notion of industrialization and inter-regional inequalities to inter-sectoral imbalances. Under the influence of this new direction, the general policy of the early seventies shifted towards poverty reduction and employment, and gave a greater priority to rural development. In conjunction with that, the new strategies were formulated as part of the regional development models with a prominent concern for integrated rural development. One such strategy of fostering rural development within the framework of regional development planning is the introduction of the Traditional Village Development Approach in the regions of Malaysia. The purpose of this paper is to examine the overall Malaysian regional development policy which have been adopted over the last thirty years, and to determine how far this approach is considerably successful, by taking PERDA (Penang Regional Development Authority) as a case, in achieving the stated objectives.

\subsection{Regional Planning in Malaysia}

The pursuit of national development in Malaysia was fundamentally prompted and spurred by the desire to promote and enhance the social and economic well-being of the people. The major objective of regional development is the reduction of disparities in development among regions. The policy statements have spelled this out in every one of Malaysia's five-year development plans, since The Second Malaysia Plan (1971-1975) until to date. 
To achieve the various goals of regional development, a number of strategies have been adopted in Malaysia. Basically four important strategies can be identified as; resource and new land development, in-situ rural development, industrial dispersal, and rural urbanization and creation of new growth centres (Alden \& Awang, 1985). The main focus of regional development has been on the opening of new land development schemes in the poorest states. A system of growth centres and corridor development was to be used to decentralize industrial development and dispersion into the less developed states (Salih \& Young, 1988). The question of why regional development had limited success is certainly correlated with the problems of the growth pole strategy. When the empirically untested concept was translated into plans and policies, there was great lack of precision, and even the type of propulsive industries to be located at the growth pole was not known (Friedmann \& Weaver, 1979). One mistake which came out of this experience was that the hinterland had to be developed in order that the growth pole succeeds, rather than the other way around. Therefore the concept that the growth centre will have spread effects to the peripheral areas is not always right.

The establishments of new townships in all the Regional Development Authority areas are also unsuccessful. There were not enough facilities, and limited off-farm employment opportunities. There was also a mismatch between physical development, such as high-standard buildings and infrastructural facilities with the needs of the local environment. In some areas there was no balance between the number of residential units and commercial facilities provided. At this stage it also became clear that the population of the traditional villages surrounding the Regional Development Authorities were not attracted to these new townships as expected.

Choguill (1985) analyzed the potential and limitations of the new towns in generating economic growth in the KETENGAH region. Even with the availability of basic infrastructure facilities, the study showed that the new towns have still not reached the stage of self-generating growth which was expected of them. In order to enhance the new towns, Choguill further suggested the need for an appropriate agricultural policy as well as adequate consideration of their economic base. Noorizan (1992), examined the actual problems of implementing the new land development scheme in the JENGKA region. The study concluded that the regional development projects did improve the socio-economic conditions of the settlers, including their income and standard of living. However the study also indicated that the younger generation intends to migrate to other areas for better job opportunities rather than to continue their parents' work.

However it is not entirely true that the regional development and growth centre strategies adopted by Malaysia did not have any significant impact especially on urbanization and regional decentralization. The Penang case is an outstanding example of a natural growth pole, through labor immigration and other inter-urban linkages with its hinterland region (Salih \& Young, 1985).

Another successful impact of regional strategies is the growth of small towns resulting from developments in a hinterland region. An immediate case is the impact of the Muda Agricultural Development Authority which is concerned with irrigation and double-cropping of rice on the growth of lower-order centres, essentially central places, in the MADA region. Therefore the overall assessment of regional development strategies and their impact in Malaysia seem to be rather mixed. However, in general, it is clear that regional development strategies cannot have the expected results unless sustained by, and integrated with the overall development strategies.

\section{The Traditional Village Development Approach}

The approach was first implemented at the end of 1984. Under this concept, there are three main aspects that have been emphasized to increase the quality and agricultural productivity through consolidation of individual small farms and paddy fields using the modern production techniques and management; to create the village industries, small industries and other non-agriculture economic activities and to restructure and regroup the scattered village into one proper settlement and equipped with basic facilities. As a result, a new growth centre is created in the rural area.

The conceptual development approach was to be implemented to achieve two main objectives; to enhance the income and standard of living and also to restructure the rural society. PERDA has already identified 26 areas inclusive of a few villages to be modernized and develop by using this strategy. PERDA has also identified five specific programmes that have to be coordinated in each village in order to accomplish the two main objectives of the approach; i) agricultural development, ii) infrastructure development, iii) housing development and urbanization, iv) industrial development and investment, v) training and community development.

\section{Methodology}

The fundamental methodology for this type of study is to estimate the differential of 'Before' and 'After' changes in terms of specified variables (Black \& Champion, 1976; Bolminck \& Nelson, 1990). Bolminck and 
Nelson (1990) further suggested that the two groups (with and without programme) must be as far as possible facing similar economic conditions, apart from getting the treatment. Ideally, changes in income or other variables can best be obtained by comparing present income status or other variables with the base-line data from some time immediately prior to the programme commencement (Riddel, 1990).

In this study, the 'Before-After' comparison involved establishing the household situation before the involvement of Perda in their village and assessing changes after the involvement of Perda. They therefore represented a 'with the programme' group, which was subjected to the Perda's intervention. On the other hand, a selected numbers of households and key-informants from other villages have been identified, as a 'without the programme' group. They were not subjected to Perda's intervention and known as a control group. A combination of three methods has been used in collecting the primary data; observation, personal interview, and depth interview. The impact survey has been carried out using techniques such as personal interviews, comprising a set of questionnaires.

\subsection{Sampling Procedure}

In this study the population elements are the households in the Perda region. A simple random sampling technique was used in the two traditional village; Kampong Kubang Menderong and Kampong Tasek. A total of 140 sample which represents $20 \%$ of the total number of households in the two study villages was chosen. To construct a 'control group', this study selects another village which has not received the Perda programme but was similar to the first in respect of other factors such as income levels, etc. These two areas; Kampong Air Melintas Besar and Kampong Junjung also represent the rural's Malay traditional village in the Perda region.

\subsection{The Needs for Evaluation Work}

Failure to implement the policies and required actions contained in plans, programmes or projects is widely recognized to be one, if not the major, weaknesses of contemporary planning in Third World countries (Seers, 1973). If a plan or project does not result in change necessary to achieve desired goals and objectives then it is, in effect, meaningless. Goals and objectives have to be translated into action and it is implementation which provides the crucial mechanism that permits this progression from plan to action and to change in those dimensions of the economic, social and physical environment that are the object of planning activity (Conyers, 1993).

Cheema (1985) states that evaluation is a comparison as well as a test of achievement. It is an attempt to judge what was happened as a result of the policy as compared with that would have happened otherwise if there had been no policy at all or if the policy had taken a different form.

The purpose of evaluation, as quoted in Curtis \& Watson (1983) is 'to learn from experience, so that what is planned for the future is better than what went before'. Furthermore, they indicate that evaluation is a complex task and a great many decisions have to be taken about how it should be organized and the type of methodology which is used.

\section{The Findings and Discussion}

The study carried out on the PERDA region still shows some failures in the agricultural improvement efforts. The deficiency in management and the crops/land suitability factors and the lack of modern production techniques influence the capacity of the agricultural projects and the improvement of the quality and productivity of agriculture. A desire to consolidate small farms into plantations has also failed. The analysis showed the failures in the process of restructuring the scattered villages into a more consolidated settlement and in setting up the rural growth centres. The effectiveness of the traditional village development approach can be seen through the small and medium scale industries development strategies and other off-farm based economic activities. These activities are capable of offering job opportunities, in a more productive sector. However, non-availability of heavy capital intensive high technology industries, to achieve a wider spatial development distribution, through the trickle-down effect, showed that this strategy is still limited. The key issues and problems in the traditional villages are related to a high incidence of poverty and lack of basic amenities and infrastructure. These structural compositions are mostly confined to agriculture and traditional settlement areas with a minimum range of retail and service sectors. Therefore the traditional villages in PERDA region could play their role as dormitory settlements, in an integrated settlement system (Rondinelli, 1983) with improvement and rehabilitation programmes in agriculture and livestock, development where appropriate small-scale and cottage industrial sectors of housing and physical and social infrastructural improvements are introduced. In order to strengthen the dormitory functions of the other traditional villages, the efficiency of transportation system and linkages to major development centers should be accorded priority. The improvement of transport facilities and 
of communications generally in the PERDA region is therefore seen to be an important element in providing the impetus for socio-economic growth.

The regional development programmes and the policies of PERDA have an in-situ pattern that does not need any restructuring or migration of people from their original settlements. However, this approach based on agricultural development has still failed to improve the socio-economic status of the villagers. Furthermore, the ad-hoc short-term projects, are incapable of venturing into more competitive market. In relation to this, the question of sustainability in development programmes becomes very crucial. Sustainability is an issue because experience with development programmes is rich with examples of donor-assisted efforts that did not bring about long-term improvements (OECD, 1989). On this basis, elements of urbanism based on an agropolitan approach (Friedmann \& Weaver, 1979) should be introduced. The agropolitan district is linked to the regional network including larger towns by physical channels of communication. These agricultural development strategies need to be backed-up with agricultural incentives such as price control and loans and to be managed in a collective organization. The development of the agricultural-based industries is an important element and the productivity gains can be achieved through regional economy, efficient physical development resources and the expansion of regional and inter-regional markets.

However, the development of non-agricultural based industries and urbanization is too strong for agriculture to compete with. As a result, labour migration occurs and the agricultural lands are left unattended. At the same time the strong tendency for industrial and commercial development to concentrate along the metropolitan corridor implies that the PERDA region would remain very much an agricultural hinterland. But, productive agricultural land is likely to give way to non-agricultural development, and the number of farm opportunities available is also anticipated to decline. The result will be that the majority of PERDA's settlements would have to play the role of dormitory towns providing housing, amenities and support services for the needed manpower of the expanding commercial and industrial activities in the metropolitan areas. Otherwise, there would be a continuous influx of population, especially the young, skilled, and better educated ones, from the rural to the metropolitan areas. The consequence might be that PERDA's area would experience a decline in population. If such a situation were allowed to take place without any intervention, the disparity between the metropolitan and PERDA's region would widen. The former would achieve greater prospects while the latter would lag behind in opportunities.

Since agricultural activities are predominant in the rural economy and provide a means of livehood for a majority of the population, the idea was accepted that agriculture would often be the starting point for rural development and rural industrialization would have a mainly supportive role. As suggested by UNIDO (1978:5), “....an early step towards rural industrialization would be to strengthen the linkages between the two sectors at the policy, planning, programme and project levels."

In view of the present constraints, the relevant long-term development strategy for the agricultural sector in Malaysia, and other developing countries, is to raise the productivity of scarce resources. The most effective way to optimize the use of scarce land and labour resources is to effect changes in the crop mix to more remunerative crops and to increase the productivity of the existing crops. There are good prospects of crop conversion away from existing crops to others such as oil palm with higher returns per unit areas of land, which may be consolidated and managed commercially as mini-estates. Furthermore, new high-yielding clones and better farm management practices are expected to push up production of crude palm oil. The use of palm oil and its by-products and the palm trees will be further diversified. Besides this, the palm oil sub-sector's contribution to total agricultural value-added is expected to increase from $41.5 \%$ in 1995 to $43.1 \%$ in year 2000 (Agatha, 1996).

The concern about the need to revitalize the agricultural sector stems from the relative decline in the performance of the sector. The programme of the revitalization of agriculture wills emphasis increasing productivity, efficiency, competitiveness and fuller utilization of existing and new resources. Since unorganized smallholders form a large segment of agricultural households, the modernization and commercialization of unorganized smallholders needs to be emphasized. Increasing participation of the private sector will be crucial in the revitalization process. These general ideas are relevant to the thrust of the National Agricultural Policy, which has the objective ..."to maximize income from agriculture through the efficient utilization of resources and the revitalization of the contribution of the sector to overall economic development (Fifth Malaysia Plan, 1986:296).

The strategy to meet this objective is not production or commodity-oriented but rather enterprise-oriented, whereby it encourages, where possible, shifts to profitable crop enterprises or cropping patterns which ensure high returns to labor and investment. In addition to the crop production sector, due cognizance should also be given to the livestock and aquaculture sectors. Small-scale projects such as sheep grazing under tree crops, duck 
egg production, quail breeding, are useful income supplementation devices, are not costly to implement nor do they involve very substantial risks. Projects such as these moreover would help promote more optimal enterprise mixes.

Strengthening intersectoral linkages forms the key issue in the revitalization of agriculture and industrial growth, which would also contribute to solving the low incomes and underemployment problems of the agricultural sector. Although maximizing existing and potential linkages and multiplier effects within and between sectors has been identified as a strategy for the manufacturing sector (Fifth Malaysia Plan, 1986:333), much has to be done to tap the full potential of the dynamic contribution of the agricultural sector in the industrialization process. The experience of establishing these linkages (agriculture-industry linkages) in some of the countries of the region, particularly in China, the Republic of Korea and Thailand, show that the strategy is not only essential but also feasible (United Nations, 1990:91).

The expansion of agro-based industries would lead revitalizing the agricultural sector, through improvements in the value-added of export crop commodities, expanded utilization of agricultural by-products for livestock feeding, and increased off-farm income-earning opportunities. Being relatively labor-intensive manufacturing establishments, they have considerable scope of absorbing underemployed labor from the traditional agricultural smallholdings. The development of these industries is not only advantageous from the perspective of absorbing surplus labor but also for linking agricultural production with the future growth of the manufacturing sector. In this case, the food processing industry is expected to contribute significantly towards employment creation and rural income generation. The Annual Report of the Sectoral Task Force on the Food Processing Industry (1990/91)) noted that this industry has the potential for forward and backward linkages with agriculture, packaging, refrigeration, processing, equipment and machinery industries. To maximize the use of local resources, large scale integrated agricultural projects could also be promoted and develop in order to achieve economies of scale in both production and marketing. Some of the large-scale integrated food processing projects identified are; fruit cultivation and processing of juices and purees, processing of animal feed, meat production and processing, aquaculture, and vegetable cultivation. Therefore, this implies the great potential for import substituting food processing industry as well as for the use of local resources for food processing (United Nations, 1990).

In conjunction with this, there is a need to increase the locational incentives to encourage agro-based industries to locate their industries in the rural areas. An improved transport and communications network would improve this situation. If rural industrialization is to be boosted for the future, there is a need to provide stronger locational incentives to attract industries to the rural areas.

The role of private sector is crucial for the revitalization of agriculture. Traditionally, their role has been in the development of tree crop agriculture for export, like rubber, oil palm and cocoa (Siwar, 1995:17). However, continued uncertainties in commodity prices, problems of high labor costs and low returns for some crops like rubber have contributed to the relative stagnation of private sector investment in agriculture. Therefore, private sector investment in food production, processing and aquaculture has to be encouraged.

The study also shows that the strategy on changes in the structure of settlement involving the relocation and consolidation of the scattered traditional homesteads and villages into centralized and well planned settlements has not been achieved. Land is a major constraint in restructuring and regrouping the scattered villages and creating new rural growth centers. Furthermore, the increasing pressures on land lead to a competitive demand/supply and conflicts in future land use. Therefore, an integrated physical and land use planning and management is believed to be a possible alternative to achieve the resolving of such conflicts and to move towards more effective and efficient use of rural land.

To be successfully adopted, planning for sustainable use of land must take full account of the characteristics of the land, available resources and social and economic factors of the environment within which planners make their decisions. The immediate challenges here are to optimize achievement of the objectives and to satisfy the needs of the actual land user and the community to which he or she belongs.

However, there are often conflicting objectives which require appropriate platforms for negotiation and decision making at all relevant levels. At village level, it is very important to create the capacity to coordinate activities and decide on land use development priorities. Other institutional forms need to be established or incorporated such as elected village land use committees, district planning committees and within PERDA itself. This is in order to deal with the overall and long-term interests of the community as a whole and the region of PERDA specifically. In this process, the element of people's participation and their contributions are essential prerequisite. Goulet in Deborah Eade (ed.) (1997:59) notes that “....participatory development claims to be 
holistic, taking into account a community's emotional, psychological, cultural and spiritual needs as well as its physical needs."

Related to the above policy implication, a creation of spatial-linkages is essentially required. A region is not just a system of functional diversified settlements but also a network of social, economic and physical interactions. The process of interactions are formed by linkages among settlements. Therefore, regional planners and policy-makers must be concerned about the effectiveness of these process on interaction and ways that provide a maximum amount of access to the population of the region. For example, once a new set of linkages is introduced into a rural market system, it can trigger a set of circular and cumulative changes that promote further growth and change (Avrom Bendavid-Val, 1991).

New physical linkages between urban centers and rural villages can change the flow of economic resources, the social pattern of interaction and the movement of people and goods. Closer interactions among villages, rural growth centres, intermediate cities and major metropolitan centers can make it more convenient to distribute widely services that are needed for regional development within the context of spatial hierarchy.

\section{Conclusion}

An evaluative research strategy especially related to the Traditional Village Development Approach to regional development in Malaysia has not been developed. Therefore, this effort is very much concerned with the quality of what actually happens on the ground. It seeks to identify the extent to which specified objectives have been achieved and their impact on the population. It operates as a mechanism for correcting deviations that may have arisen between what was intended to be done and what has actually been done. These contributions are best described by Curtis and Watson (1983:4), “...to learn from experience, so that what is planned for the future is better than went before."

For PERDA, even though the spread effects are still limited, it could still achieve a wider spatial development distribution through efficient physical development resources, strengthening the intersectoral linkages, expansion of regional and inter-regional markets, providing a stronger locational incentives and encouraging the role of private sector.

\section{References}

Agatha Matayun. (1996, May 7). Getting a better yield from farms. The Star On-Line.

Alden, J. D., \& A. H. Awang. (1985). Regional development planning in Malaysia. Regional Studies, 19.

Avrom Bendavid-Val. (1991). Rural area development planning: principles, approaches and tools of economic analysis. Food and agriculture organization of the United Nations, Rome.

Black, J. A., \& Champion, D. J. (1976). Methods and issues in social research. John Wiley \& Sons.

Bolminck, B. R., \& Nelson, E. R. (1990). Evaluating the economic impact of a special credit programme in Indonesia. The Journal of Developing Studies, 20(2).

Cheema, G. S. (1985). Rural development in Asia. New York: Sterling Publishers Private Limited.

Choguill, C. L. (1985). Small towns and development: A study from Malaysia, TRP 62, Department of Town and Regional Planning, University of Sheffield.

Conyers, D. (1993). Guidelines on social analysis for rural areas development planning. FAO, Rome.

Curtis, D., \& J. R. Watson. (1983). A guide to monitoring and evaluation for district offices, University of Birmingham, Institute of Local Government Studies, development administration group occasional paper 19.

Deborah Eade (Ed.). (1997). Development in practice, 7(1). Oxford: United Kingdom.

Friedmann, J., \& Clyde Weaver (1979). Territory and function: The evolution of regional planning. Berkeley: Edward Arnold.

Malaysia. (1971). Second Malaysia Plan (1971-1975). Kuala Lumpur: National Printing Department.

Malaysia. (1986). Fifth Malaysia Plan (1986-1990). Kuala Lumpur: National Printing Department.

Noorizan Nor. (1992). The new land development scheme: A case study of JENGKA region. University of Sheffield.

OECD. (1989). Sustainability in development programmes: a compendium of evaluation experience. Paris.

Riddle, R. (1990). Judging success-evaluating NGO approaches to alleviating poverty in developing countries. 
IT Publication.

Rondinelli, D. A. (1983). Secondary cities in developing countries: Policies for diffusing urbanization. Beverly Hills: Sage Publications.

Salih, Kamal, \& Young, Mei Ling. (1988, April). Evaluation of Regional Development Experience in Malaysia. Malaysian Institute of Economic Research, (13).

Seers, D. (1973). The meaning of development. In Charles K. Wilber (Ed.), The political economy of development and underdevelopment. New York: Random House.

Siwar Chamhuri. (1995). Revitalization of agriculture: the basis of industrial growth and restructuring. MIER, Kuala Lumpur.

UNIDO. (1978). Industrialization and rural development. New York: United Nations Publication.

United Nations. (1990). Strategy for rural poverty alleviation: agriculture-industry linkages. Economic and Social Commission for Asia and The Pacific, Bangkok. 